https://doi.org/10.19195/1733-5779.32.3

\title{
Dorobek doktora Marcina Winiarskiego
}

\section{Bibliografia}

\section{Artykuły}

1980

Innowacje rynkowe w strategii i taktyce przedsiębiorstwa, [w:] Aktualne problemy naukowo-badawcze budownictwa, Krynica, [16-23 września] 1980, t. 8. Referaty. Problemy remontów rekonstrukcji i modernizacji budynków/XXVI konferencja naukowa, Wrocław 1980, s. 153-169.

Komponenty systemu promocji w realizacji strategii przedsiębiorstwa, [w:] Propaganda gospodarcza i promocja jako czynniki kształtujace model spożycia. Materiały na konferencje naukową, Łódź, [15-17 stycznia 1981], Łódź 1980, s. $35-48$.

\section{1}

[współautorzy: Z. Szalbierz, K. Wilczewska, W. Wilczewski] Zasady i metody badań rynkowych, Raporty Inst. Nauk Społ. PWr 1981, Ser. SPR, nr 3, 47 s.

[współautorzy: J. Szczygielski, Z. Szalbierz, K. Wilczewska, Witold Wilczewski] Założenia i metody oceny poziomu technicznego sprzętu radiotechnicznego, Raporty Inst. Nauk Społ. PWr 1981, Ser. SPR, nr 5, 20 s.

[współautorzy: K. Kolasiński, J. Szczygielski, Zdzisław Szalbierz, Krystyna Wilczewska, Witold Wilczewski] Kryteria oceny nowoczesności i metody wyboru sprzętu radiofonicznego w etapie przedprodukcyjnym, Raporty Inst. Nauk Społ. PWr 1981, Ser. SPR, nr 6, 69 s. 
1982

[współautorzy: Z. Szalbierz, J. Szczygielski, K. Wilczewska, W. Wilczewski] Identyfikacja własności uzytkowych sprzętu radiofonicznego. Cz. 1, Raporty Inst. Nauk Ekon.-Społ. PWr 1982, Ser. SPR, nr 2, 39 s.

1984

[współautorzy: Z. Szalbierz, J. Szczygielski, K. Wilczewska, W. Wilczewski] Identyfikacja własności użytkowych sprzętu radiofonicznego. Cz. 2, Raporty Inst. Nauk Ekon.-Społ. PWr 1984, Ser. SPR, nr 1, 29 s.

[współautorzy: Z. Szalbierz, J. Szczygielski, K. Wilczewska, W. Wilczewski] Metody i procedura oceny poziomu technicznego sprzętu radiofonicznego, Raporty Inst. Nauk Ekon.-Społ. PWr 1984, Ser. SPR, nr 2, 77 s.

1985

Reforma gospodarcza a strategia działania przedsiębiorstw, [w:] Wdrażanie reformy gospodarczej. Materiały IV Szkoły Ekonomii Uniwersytetu Wrocławskiego. Karpacz, 17-23 stycznia 1983 r., Wrocław 1985, s. 91-99, bibliogr.

1990

Założenia urynkowienia gospodarki i podmiotowości przedsiębiorstw a przebudowa systemu planowania, [w:] Planowanie i polityka ekonomiczna, „Prace Naukowe Akademii Ekonomicznej im. Oskara Langego we Wrocławiu" 515, 1990, s. [55]-64, streszcz. w jęz. niem. i ros.

1994

Efekty procesów dostosowawczych — pozycja krajów nowo uprzemystowionych w międzynarodowym podziale pracy, [w:] Procesy dostosowawcze w gospodarce światowej w latach dziewięćdziesiatych: aspekty teorii i polityki międzynarodowej wspótpracy gospodarczej red. L. Olszewski („Ekonomia” 1), Wrocław 1994, s. 85-97, bibliogr., streszcz. w jęz. ang.

Relacje przedsiębiorstwo-otoczenie, [w:] Rola państwa w gospodarce otwartej, red. L. Olszewski, Wrocław 1994, s. 137-143, bibliogr., streszcz. w jęz. ang.

1995

[współautorzy: L. Olszewski, Z. Juchymiuk, D. Lee] Porter's model: what can economies in transition learn, [w:] Otwarcie gospodarki polskiej 1990-1993: teorie gospodarki otwartej, doświadczenia krajów zachodnich w zakresie otwarcia gospodarki, relacje gospodarki polskiej z rynkami zagranicznymi, red. L. Olszewski, Wrocław 1995, s. 105-122, bibliogr. Referat wygłoszony na konferencji zorganizowanej przez Zakład Międzynarodowych Stosunków Ekonomicznych Instytutu Nauk Ekonomicznych Uniwersytetu Wrocławskiego w listopadzie 1993 roku. 
1996

[współautor: L. Olszewski] Internationalisation, globalisation et la hierarchie des groupes sociaux dans le pays en transition, [w:] Les strategies des groupes sociaux victimes de la globalisation de l'economie: colloque des 12, 13 et 14 janvier 1995, Centre de Recherche sur le Développement Université de Neuchâtel, red. S. Honsberger, Neuchâtel 1996, s. [233]-249, bibliogr.

1997

Kształtowanie sieci dystrybucyjnych, [w:] Struktury przemysłowe w gospodarce: aspekty ekonomiczne, społeczno-kulturowe i polityczne, red. L. Olszewski, J. Mozrzymas, Wrocław 1997, s. 221-240, bibliogr., streszcz. w jęz. ang.

Przemiany $w$ polskim handlu detalicznym i hurtowym w latach 1990-1994, [w:] Ewolucja polityki ekonomicznej w gospodarce rynkowej, red. L. Olszewski (,Ekonomia” 4), Wrocław 1997, s. 135-142, bibliogr., streszcz. w jęz. ang.

1999

Badania marketingowe rynków zagranicznych, „Roczniki Naukowe Wyższej Szkoły Zarządzania i Marketingu we Wrocławiu” 2, 1999, z. 2, s. 101-122.

Badania marketingowe rynków zagranicznych - nowe wyzwania i możliwości, [w:] Problemy globalizacji, regionalizacji i transformacji gospodarki dekady lat dziewięćdziesiątych, red. L. Olszewskiego („Ekonomia” 6), Wrocław 1999, s. 69-86, bibliogr., streszcz. w jęz. ang.

2000

Promocja na rynkach zagranicznych - wybrane zagadnienia, [w:] Dynamika procesów wzrostu gospodarczego i integracji drugiej połowy XX wieku, red. L. Olszewski („Ekonomia” 7), 2000, s. 271-290, bibliogr., streszcz. w jęz. ang. [współautor: L. Olszewski] Le tissu industriel dans le processus de transition, [w:] Qui contribue à la désindustralisation des régions fragilisées? Colloque des 25-26 mai 2000, red. A. Sagarra, Neuchâtel 2000, s. 127-144.

2001

Procesy globalizacji a rozwój handlu elektronicznego, [w:] Międzynarodowy podziat pracy - integracja europejska - restrukturyzacja: tendencje i doświadczenia, red. L. Olszewski („Ekonomia” 9), Wrocław 2001, s. 33-51, bibliogr., streszcz. w jęz. ang.

SWOT/TOWS analiza, [w:] Jakość kształcenia w szkolnictwie wyższym: słownik tematyczny, red. M. Wójcicka, Warszawa 2001, s. 113-117, bibliogr.

Wywiad grupowy zogniskowany, [w:] Jakość ksztatcenia w szkolnictwie wyższym: słownik tematyczny, red. M. Wójcicka, Warszawa 2001, s. 133-135, bibliogr. 
2003

Glocalisation and segmentation of the world market, [w:] Gospodarka narodowa i przedsiębiorstwa na poczatku XXI wieku = L'économie nationale et les entreprises au debut du XXIème siècle: la mondialisation: impacts sur les changements technologiques des firmes, répercussion sur les politiques des états, red. L. Olszewski, [Wrocław] 2003, s. 173-180, bibliogr. Materiały z konferencji międzynarodowej zorganizowanej przez Instytut Nauk Ekonomicznych w dniach 9-11 maja 2002 roku w ramach obchodów 300-lecia Uniwersytetu Wrocławskiego.

[współautor: L. Olszewski] La concentration et la globalisation du commerce de detail et de gros : le cas de la Pologne, [w:] Mutations contemporaines et developpement/Coordonnateurs Claude Albagli, Sahondravololona Rajemison. Collection Mouvements Economiques et Sociaux, [Paris] Institut Cedimes, L'Harmattan, 2003, s. [129]-151. Materiały z XIII seminarium międzynarodowego Instytutu Cedimes, które odbyło się w Antananarywie na Madagaskarze w 2003 roku.

2005

Marketing blog — terra incognito?, [w:] Marketing przyszłości: trendy, strategie, instrumenty: media w kreowaniu wizerunku, cz. 2, [red. nauk. G. Rosa, A. Smalec], „Zeszyty Naukowe Uniwersytetu Szczecińskiego” nr 414, Szczecin 2005, s. 689-696.

Wyzwania nowej przestrzeni rynkowej, [w:] Rozszerzenie Unii Europejskiej: korzyści i koszty dla nowych krajów członkowskich, red. J. Kundera, Wrocław 2005, s. 324-341, bibliogr. Materiały z konferencji zorganizowanej we Wrocławiu w dniach 20-21 maja 2004 roku przez Instytut Nauk Ekonomicznych Uniwersytetu Wrocławskiego, Polskie Towarzystwo Ekonomiczne O. Wrocław i Ośrodek Badań i Dokumentacji Unii Europejskiej.

2007

Private labels $w$ strategiach globalnych detalicznych sieci handlowych, [w:] Zarzqdzanie marketingowe we współczesnym handlu i ustugach, red. H. Bronakowski, E. Hościłowicz, U. Widelska, Białystok 2007, s. 145-151, bibliogr., streszcz. w jęz. ang.

Strategie marketingowe przedsiębiorstw na rynkach EU: segment wyżu demograficznego (Baby Boomers), [w:] Stosunki ekonomiczne w rozszerzonej Unii Europejskiej = Economic Relations in the EU Enlarged, red. J. Kundera, Wrocław 2007, s. 145-160, bibliogr. Referat wygłoszony na międzynarodowej konferencji zorganizowanej na Wydziale Prawa, Administracji i Ekonomii w dniach 11-12 maja 2006 roku. 
2008

Informacja o Naukowym Kole Ekonomistów, „Studenckie Prace Prawnicze, Administratywistyczne i Ekonomiczne” 5, 2008, s. 9-12, http:/wuwr.pl/sppae/ article/view/8858/8474.

\section{0}

Teraźniejszość i przyszłość marketingu w Polsce i na Ukrainie, [w:] Polska i Ukraina na drodze do wspólnej Europy: Dni Uniwersytetu Lwowskiego im. I. Franki na Uniwersytecie Wrocławskim 2009, red. M. Winiarski, Wrocław 2010, s. 119-131, bibliogr., streszcz. w jęz. ang.

2011

Surving strategies in marketing management, [w:] Globalizacja, europejska integracja a kryzys gospodarczy = Globalization, European Integration and Economic Crisis, red. J. Kundera, Wrocław 2011, s. 217-234, bibliogr. Materiały z konferencji, Wrocław, 23-24 kwietnia 2010 roku, http://www.bibliotekacyfrowa.pl/Content/35505/001.pdf.

\section{5}

Etyka a zarzadzanie marketingowe: wybrane problemy, „Wrocławsko-Lwowskie Zeszyty Prawnicze” 2015, nr 6, s. 189-204, bibliogr., streszcz. w jęz. ang. Tekst także w przekł. na jęz. ukr. pt. Etika ta marketingove upravlinnâ: vibranì problemi, s. 205-219.

\section{Prace redakcyjne}

\section{4}

„Studenckie Prace Prawnicze, Administratywistyczne i Ekonomiczne” 2004, nr 2, 140 s., [M. Winiarski, Wstęp, s. 7-8], bibliogr. przy art., tekst w jęz. ang., https:// www.bibliotekacyfrowa.pl/dlibra/publication/28279/edition/34833.

2005

„Studenckie Prace Prawnicze, Administratywistyczne i Ekonomiczne” 2005, nr 3, 145 s., [M. Winiarski, Wstep, s. 7], bibliogr. przy art., https://www.bibliotekacyfrowa.pl/dlibra/publication/28287/edition/34840.

2006

„Studenckie Prace Prawnicze, Administratywistyczne i Ekonomiczne” 2006, nr 4, 227 s., [M. Winiarski, Wstęp, s. 7-8], bibliogr. przy art., http://www.bibliotekacyfrowa.pl/Content/34703/002.pdf. 
2008

„Studenckie Prace Prawnicze, Administratywistyczne i Ekonomiczne” 2008, nr 5, 152 s., [M. Winiarski, Wstęp, s. 7-8], bibliogr. przy art., http:/wuwr.pl/sppae/ issue/view/54.

\section{9}

Nowe idee początku XXI wieku Wrocław 2009, 115 s., [M. Winiarski, Wstęp, s. 7-8], bibliogr. przy rozdz., streszcz. w jęz. ang. przy rozdz., https://bibliotekacyfrowa. $\mathrm{pl} / \mathrm{dlibra} /$ publication/20501/nowe-idee-poczatku-xxi-wieku?language $=$ pl\#structure.

„Studenckie Prace Prawnicze, Administratywistyczne i Ekonomiczne” 2009, nr 6, 160 s., [M. Winiarski, Wstęp, s. 7-8], bibliogr. przy art., http://wuwr.pl/sppae/ issue/view/538.

\section{0}

Polska i Ukraina na drodze do wspólnej Europy: Dni Uniwersytetu Lwowskiego im. I. Franki na Uniwersytecie Wrocławskim 2009, Wrocław 2010, 165 s., bibliogr. przy rozdz., jedna praca w jęz. ukr.

„Studenckie Prace Prawnicze, Administratywistyczne i Ekonomiczne” 2010, nr 7, 136 s., [M. Winiarski, Wstęp, s. 7-8], bibliogr. przy art., streszcz. w jęz. ang. przy rozdz. Pierwszy tom materiałów z VII Międzynarodowej Konferencji Naukowej pt. Konsument, przedsiębiorstwo, gospodarka światowa. Determinanty i skutki postępu technicznego, która odbyła się w dniach 4-6 grudnia 2009 roku we Wrocławiu i Kudowie-Zdroju, http://wuwr.pl/sppae/issue/view/537.

„Studenckie Prace Prawnicze, Administratywistyczne i Ekonomiczne” 2010, nr 8, 118 s., [M. Winiarski, Wstęp, s. 7-8], bibliogr. przy art., streszcz. w jęz. ang. przy art. Drugi tom materiałów z VII Międzynarodowej Studenckiej Konferencji Naukowej pt. Konsument, przedsiębiorstwo, gospodarka światowa. Determinanty i skutki postępu technicznego, która odbyła się w dniach 4-6 grudnia 2009 roku we Wrocławiu i Kudowie-Zdroju, http://wuwr.pl/sppae/issue/view/536.

\section{1}

Gospodarka: innowacje i rozwój, Wrocław 2011, 136 s., [M. Winiarski, Wstęp, s. 9-10], bibliogr. przy rozdz., tekst w jęz. pol., część. ang.; streszcz. w jęz. ang. i pol. Materiały z seminarium naukowego „Gospodarka: innowacje i rozwój”, które odbyło się na Uniwersytecie Wrocławskim w czerwcu 2010 roku, https:// www.bibliotekacyfrowa.pl/dlibra/publication/31779/edition/37108/content.

„Studenckie Prace Prawnicze, Administratywistyczne i Ekonomiczne” 2011, nr 9, 107 s., [M. Winiarski, Wstęp, s. 7-8], bibliogr. przy art., http:/wuwr.pl/sppae/ issue/view/535. 
„Studenckie Prace Prawnicze, Administratywistyczne i Ekonomiczne” 2011, nr 10, 107 s., [M. Winiarski, Wstęp, s. 7-9], bibliogr. przy art., dwa art. w jęz. ang., streszcz. w jęz. ang., http://wuwr.pl/sppae/issue/view/534.

„Studenckie Prace Prawnicze, Administratywistyczne i Ekonomiczne” 2011, nr 11, 139 s., [M. Winiarski, Wstęp, s. 7-8], bibliogr. przy art., art. częśc. w jęz. ang., streszcz. w jęz. ang., http://wuwr.pl/sppae/issue/view/539.

2012

The Leading Edge: New Ideas, Problems and Challenges of the Economics, Management and Marketing, Wrocław 2012, 150 s. [M. Winiarski, Introduction, s. 7-9], bibliogr. przy rozdz., streszcz. w jęz. ang. przy rozdz. Materiały z konferencji zorganizowanej we Wrocławiu w grudniu 2011 roku przez Instytut Nauk Ekonomicznych Wydziału Prawa, Administracji i Ekonomii, Polskie Towarzystwo Ekonomiczne Oddział Wrocław i Naukowe Koło Ekonomistów. „Studenckie Prace Prawnicze, Administratywistyczne i Ekonomiczne” 2012, nr 12, 117 s., [M. Winiarski, Wstęp, s. 9; Preface, s. 11], bibliogr. przy art., art. częśc. w jęz. ang., streszcz. w jęz. ang., http://wuwr.pl/sppae/issue/view/542.

2013

„Studenckie Prace Prawnicze, Administratywistyczne i Ekonomiczne” 2013, nr 13, 116 s., [M. Winiarski, Wstęp, s. 9-11], bibliogr. przy art., art. część. w jęz. ang., streszcz. w jęz. ang., pol., http://wuwr.pl/sppae/issue/view/543.

„Studenckie Prace Prawnicze, Administratywistyczne i Ekonomiczne” 2013, nr 14, 150 s., [M. Winiarski, Wstęp, s. 9], bibliogr. przy art., streszcz. w jęz. ang., pol., http://wuwr.pl/sppae/issue/view/544.

\section{4}

„Studenckie Prace Prawnicze, Administratywistyczne i Ekonomiczne” 2014, nr 15, 2014, 182 s., [M. Winiarski, Wstęp, s. 9-12], bibliogr. przy art., jeden tekst w jęz. ang., streszcz. w jęz. ang., pol. przy art., http://wuwr.pl/sppae/issue/view/545. „Studenckie Prace Prawnicze, Administratywistyczne i Ekonomiczne” 2014, nr 16,

222 s., [M. Winiarski, Wstep, s. 9-10, Preface, s. 11-12], bibliogr. przy art., streszcz. w jęz. ang., pol., jeden tekst w jęz. ang., http://wuwr.pl/sppae/issue/ view/546.

\section{5}

„Studenckie Prace Prawnicze, Administratywistyczne i Ekonomiczne” 2015, nr 17, 234 s., [M. Winiarski, Wstęp, s. 9-11], bibliogr. przy art., jeden tekst w jęz. ang., streszcz. w jęz. pol., ang. przy art., http://wuwr.pl/sppae/issue/view/547. 
„Studenckie Prace Prawnicze, Administratywistyczne i Ekonomiczne” 2015, nr 18, 173 s., [M. Winiarski, Wstęp, s. 9-12], bibliogr przy art., http:/wuwr.pl/sppae/ issue/view/548.

\section{6}

„Studenckie Prace Prawnicze, Administratywistyczne i Ekonomiczne” 2016, nr 19, 203 s. [M. Winiarski, Wstep, s. 9-10; Introduction, s. 11-12], bibliogr. przy art., streszcz. w jęz. ang. przy art., http://wuwr.pl/sppae/issue/view/549.

\section{Działalność naukowo-organizacyjna}

Doktor Marcin Winiarski był współorganizatorem Konferencji Międzynarodowej Gospodarka narodowa i przedsiębiorstwa na początku XXI wieku. Globalizacja: wpływ przemian technologicznych na firmy, reperkusje w polityce państw, która odbyła się w dniach 9-10.05.2002 roku we Wrocławiu na Wydziale Prawa, Administracji i Ekonomii Uniwersytetu Wrocławskiego.

\section{Konferencje Naukowego Koła Ekonomistów organizowane przez doktora Marcina Winiarskiego}

Międzynarodowa Konferencja Problemy polityki gospodarczej na tle procesów integracji i globalizacji gospodarki, która odbyła się 21-23.11.2003 roku we Wrocławiu na Wydziale Prawa, Administracji i Ekonomii.

II Międzynarodowa Konferencja Problemy polityki gospodarczej na tle procesów integracji i globalizacji gospodarki, która odbyła się w grudniu 2004 roku we Wrocławiu na Wydziale Prawa, Administracji i Ekonomii.

III Międzynarodowa Konferencja NKE Konsument, przedsiębiorstwo, gospodarka światowa, która odbyła się 2-4.12.2005 roku we Wrocławiu na Wydziale Prawa, Administracji i Ekonomii.

IV Międzynarodowa Konferencja NKE Konsument, przedsiębiorstwo, gospodarka światowa, która odbyła się 1-3.12.2006 roku we Wrocławiu na Wydziale Prawa, Administracji i Ekonomii.

Ogólnopolska konferencja Warto być bizneswoman, która odbyła się 22.03.2007 roku we Wrocławiu na Wydziale Prawa, Administracji i Ekonomii.

V Międzynarodowa Konferencja NKE Konsument, przedsiębiorstwo, gospodarka światowa. Społeczno-ekonomiczne wyzwania integracji, która odbyła się w grudniu 2007 roku we Wrocławiu na Wydziale Prawa, Administracji i Ekonomii.

VI Międzynarodowa Studencka Konferencja Naukowa Konsument, przedsiębiorstwo, gospodarka światowa. Przyczyny i skutki nierównomiernego rozwoju gospodarczego, która odbyła się 12-14.12.2008 roku we Wrocławiu i Kudowie-Zdroju.

Dzień Ekonomii - 12.03.2009 roku i seminarium Nowe idee początku XXI wieku na Wydziale Prawa, Administracji i Ekonomii. 
Panel prawno-ekonomiczny Polska i Ukraina na drodze do wspólnej Europy, który odbył się 5-6.06.2009 roku w ramach Dni Uniwersytetu Lwowskiego im. Iwana Franki na Uniwersytecie Wrocławskim.

VII Międzynarodowa Studencka Konferencja Naukowa Konsument, przedsiębiorstwo, gospodarka światowa. Determinanty i skutki postępu technicznego, która odbyła się w grudniu 2009 roku we Wrocławiu i Kudowie-Zdroju. Konferencja była połączona z panelem dyskusyjnym w formie debaty oksfordzkiej: $C z y$ warunki prawne i instytucjonalne $w$ Polsce sprzyjaja postępowi technicznemu?

Dzień Ekonomii na Wydziale Prawa, Administracji i Ekonomii, 24.03.2010 roku. Seminarium naukowe Gospodarka: innowacje i rozwój, które odbyło się na Uniwersytecie Wrocławskim w czerwcu 2010 roku. Seminarium zostało połączone z obchodami ważnych rocznic - urodzinami oraz początkiem kariery dydaktyczno-naukowej prof. dr. hab. Leona Olszewskiego.

VIII Międzynarodowa Studencka Konferencja Naukowa Gospodarka światowa, przedsiębiorstwo, konsument. Tendencje rozwoju gospodarki światowej, która odbyła się 3-5.12.2010 roku we Wrocławiu na Wydziale Prawa, Administracji i Ekonomii.

Dzień Ekonomii na Wydziale Prawa, Administracji i Ekonomii, 16.03.2011 roku. IX Międzynarodowa Studencka Konferencja Naukowa Człowiek, rodzina i spoteczeństwo w obliczu kryzysu zadtużeniowego, której organizatorami byli Instytut Nauk Ekonomicznych i Naukowe Koło Ekonomistów wraz z Polskim Towarzystwem Ekonomicznym — Oddział Wrocławski w grudniu 2011 roku. X Międzynarodowa Studencka Konferencja Naukowa Konsument, przedsiębiorstwo, gospodarka światowa - w poszukiwaniu nowych paradygmatów, która odbyła się w 30.11-1.12.2012 roku we Wrocławiu na Wydziale Prawa, Administracji i Ekonomii.

Dzień Ekonomii na Wydziale Prawa, Administracji i Ekonomii, 17.04.2013 roku.

XI Międzynarodowa Studencka Konferencja Naukowa, Człowiek, przedsiębiorstwo, gospodarka światowa: II dekada XXI wieku — problemy i rozwiazania, która odbyła się w dniach 6-7.12.2013 roku na Wydziale Prawa, Administracji i Ekonomii.

XII Międzynarodowa Studencka Konferencja Naukowa Konsument, przedsiębiorstwo, gospodarka światowa: 25/10 zmian systemowych/członkostwa w Unii Europejskiej, która odbyła się 5-6.12.2014 roku na Wydziale Prawa, Administracji i Ekonomii.

Dzień Ekonomii - Ekonomia czasu wolnego, 25.03.2015 roku. Konferencja: Ekonomiczno-społeczne aspekty czasu wolnego na Wydziale Prawa, Administracji i Ekonomii.

XIII Międzynarodowa Studencka Konferencja Naukowa Konsument, przedsiębiorstwo, gospodarka światowa: praca, płaca, migracje, która odbyła się 4-5.12.2015 roku we Wrocławiu na Wydziale Prawa, Administracji i Ekonomii. 
Dzień Ekonomii - Ekonomia, polityka i media, 6.04.2016 roku. XIV Międzynarodowa Studencka Konferencja Naukowa Człowiek, przedsiębiorstwo, gospodarka światowa: Wyzwania srebrnej gospodarki, która odbyła się 2-3.12.2016 roku we Wrocławiu na Wydziale Prawa, Administracji i Ekonomii.

\section{Współpraca z innymi podmiotami}

W 2003 roku rozpoczęła się współpraca ze studentami i pracownikami Narodowego Uniwersytetu Lwowskiego im. Iwana Franki i do 2016 roku miała miejsce wymiana studentów - studenci ze Lwowa uczestniczyli w międzynarodowych konferencjach organizowanych na początku grudnia każdego roku na Wydziale Prawa Administracji i Ekonomii we Wrocławiu, a członkowie NKE w konferencjach organizowanych w połowie maja na Uniwersytecie we Lwowie.

W 2005 roku współuczestnictwo w III Międzynarodowej Studenckiej Konferencji Naukowej NKE Koła Naukowego Ogólnej Teorii Ekonomii im. Ludwiga von Misesa prowadzonego przez prof. Witolda Kwaśnickiego.

W 2007 roku w V Międzynarodowej Konferencji NKE uczestniczyli stypendyści Fundacji L. Kirklanda i Studiów Wschodnich Rządu Rzeczypospolitej Polskiej.

Od 2009 roku współpraca z Wrocławskim Parkiem Technologicznym przy organizacji Międzynarodowych Studenckich Konferencji Naukowych i wydaniach „Studenckich Prac Prawniczych, Administratywistycznych i Ekonomicznych”.

W 2011 roku współorganizatorem IX Międzynarodowej Studenckiej Konferencji Naukowej było Polskie Towarzystwo Ekonomiczne — Oddział Wrocławski.

Od 2012 roku istniała współpraca przy kolejnych konferencjach NKE i wydaniach „Studenckich Prac Prawniczych, Administratywistycznych i Ekonomicznych” z Fundacją „Pro Mathematica”, zajmującą się przede wszystkim organizowaniem i wspieraniem inicjatyw propagujących wiedzę matematyczną wśród dzieci i młodzieży.

Od 2013 roku współpraca z Centre d'Etudes du Développment International et des Mouvements Economiques et Sociaux (CEDIMES) i CEDIMES Polska.

We współpracy z Akademią Sztuk Pięknych na Wydziale Prawa, Administracji i Ekonomii Uniwersytetu Wrocławskiego w 2014 i 2015 roku przygotowane zostały dwie wystawy prac plastycznych pod nazwą Spotkania przyjaciót.

Doktor Marcin Winiarski sprawował opiekę nad Naukowym Kołem Ekonomistów na Wydziale Prawa, Administracji i Ekonomii Uniwersytetu Wrocławskiego od momentu jego powstania, to jest od maja 2001 do 2016 roku, oraz redagował od drugiego do dziewiętnastego numeru czasopismo „Studenckie Prace Prawnicze, Administratywistyczne i Ekonomiczne”. W 2013 roku w „Studenckich Pracach” pojawił się dział zatytułowany Zdaniem Naszych Mistrzów, w którym publikowali swoje recenzje i artykuły pracownicy naukowi Wydziału Prawa, Administracji i Ekonomii. Wśród autorów recenzji książek byli: U. Kalina-Prasznic (Michell A. Orenstein, Prywatyzacja emerytur. Transnarodowa kampania na rzecz reformy 
zabezpieczenia społecznego, Warszawa 2013), L. Klat-Wertelecka [Praca zbiorowa] Mediacje w społeczeństwie otwartym, red. M. Tabernacka, R. Raszewska-Skałecka, Wrocław 2012), P. Jurek (L. Krzyżanowski, Historia ustroju i prawa w Polsce. Repetytorium, Bielsko-Biała 2013), J. Kundera (R. Charana, Global Tilt. Leading Your Business through the Great Economic Power Shift, 2015), P. Borszowski (P. Selera, Prawo do odliczenia $i$ zwrotu podatku naliczonego w VAT, Warszawa 2014), A. Borkowski (M. Etel, Pojęcie przedsiębiorcy $w$ prawie polskim i prawie Unii Europejskiej oraz w orzecznictwie sadowym, Warszawa 2012), K. Kiczka (K. Kokocińska, Prawny mechanizm prowadzenia polityki rozwoju $w$ zdecentralizowanych strukturach władzy publicznej, Poznań 2014), a autorami artykułów: E. Wójtowicz, R. Stefanicki, Obowiązkowe ubezpieczenie odpowiedzialności cywilnej organizatora meczu piłki nożnej za szkody wyrzadzone w czasie jego trwania, A. Ćwiąkała-Małys, I. Piotrowska, Zmiana opodatkowania obrotu suszem tytoniowym akcyza próba ograniczenia szarej strefy w Polsce, T. Bednarski, Kryteria konwergencji — dokad zmierza Unia Europejska, E. Kowalczyk, Zjawiska kryzysowe - geneza $i$ wyzwania dla państwa $w$ ujęciu Wincentego Stysia, W. Kwaśnicki, Czy podręczniki ekonomii musza być tak bardzo podobne do siebie? (Logika ekonomii Marka Skousena), T. Korbutowicz, Jerzy Chodorowski teoretyk ekonomii i historyk myśli ekonomicznej.

Doktor Marcin Winiarski razem z członkami NKE prowadził wieloletnie badania metodą Focus Group Interview wykorzystywane do oceny jakości procesu dydaktycznego i studiowania, wizerunku Wydziału i Uniwersytetu Wrocławskiego oraz oceny przydatności praktyk studenckich. Z badań sporządzane były raporty dołączane do oceny wewnętrznej Wydziału i stanowiły one element Systemu Zapewniania Jakości. W 2005 roku i w kolejnych latach na zlecenie dziekana Wydziału Prawa, Administracji i Ekonomii przeprowadzane były projekty badawcze i sporządzane raporty Ocena przydatności praktyk studenckich w karierze zawodowej oraz ocena możliwości wykorzystania wiedzy teoretycznej zdobytej na studiach w praktyce w opinii studentów Wydziału Prawa, Administracji i Ekonomii Uniwersytetu Wrocławskiego i Ocena przydatności praktyk studenckich w karierze zawodowej oraz ocena możliwości wykorzystania wiedzy teoretycznej zdobytej na studiach $w$ praktyce.

NKE, nad którym opiekę sprawował dr Marcin Winiarski, uzyskało liczne nagrody i wyróżnienia, w tym:

— dyplom uznania od Rady Kół Naukowych dla Najlepszego Koła Naukowego w roku 2008 na Wydziale Prawa, Administracji i Ekonomii;

- dyplom od Uniwersytetu Wrocławskiego dla Naukowego Koła Ekonomistów za ponadprzeciętną aktywność w roku 2009, a tym samym zajęcie I miejsca na Wydziale Prawa, Administracji i Ekonomii;

- dyplom od Uniwersytetu Wrocławskiego dla Naukowego Koła Ekonomistów za zajęcie II miejsca pod względem aktywności w roku 2010 na Wydziale Prawa, Administracji i Ekonomii; 
- dyplom od Uniwersytetu Wrocławskiego i Rady Kół Naukowych dla Naukowego Koła Ekonomistów za zdobycie Nagrody Rady Kół Naukowych dla najaktywniejszego z kół naukowych Uniwersytetu Wrocławskiego w roku 2012;

— podziękowanie od koordynatorów projektu Progress Accouting Competition za współpracę przy organizacji Ogólnopolskiego Konkursu z Rachunkowości, Progress Accounting Competition, który odbył się na Uniwersytecie Łódzkim.

Przykładowe seminaria, panele dyskusyjne organizowane w ramach NKE:

— w 2006 roku seminarium Przedsiębiorstwo a gospodarka światowa;

— w 2009 roku seminarium Nowe idee poczatku XXI wieku na Uniwersytecie Wrocławskim;

— w 2010 roku seminarium Gospodarka: innowacje i rozwój na Wydziale Prawa, Administracji i Ekonomii Uniwersytetu Wrocławskiego;

— w 2013 roku panel dyskusyjny Problemy demokracji w Polsce zorganizowany przy udziale Fundacji Sapere Aude i Samorządu Studenckiego Uniwersytetu Wrocławskiego;

— w 2013 roku panel dyskusyjny Zagrożenie dla wolności gospodarczej w Polsce NKE wraz z Samorządem Studentów Uniwersytetu Wrocławskiego i Fundacją Sapere Aude;

— w 2013 roku panel dyskusyjny Problemy współpracy gospodarczej Ukrainy $z$ UE NKE i Instytut CEDIMES Polska (udział wzięli pracownicy naukowi z Uniwersytetu we Lwowie);

— w 2013 roku panel dyskusyjny Gospodarka dekady Gierka: rozwój czy wstęp do kryzysu? zorganizowany we współpracy ze Stowarzyszeniem „Pokolenia" - Oddział Dolny Śląsk i Ośrodkiem Myśli Społecznej im. Ferdynanda Lassalle'a we Wrocławiu;

— w 2014 roku panel dyskusyjny Systemowe rozwiąania ochrony środowiska;

— w 2014 roku panel dyskusyjny Ocena efektów 25 lat przemian ustrojowych i 10 lat w Unii Europejskiej we współpracy z PTE - Oddział we Wrocławiu, CEDIMES Polska.

NKE pod kierunkiem dr. Marcina Winiarskiego w 2008 i 2009 roku organizowało zbiórkę charytatywną dla dzieci Zakładu Opiekuńczo-Leczniczego w Wierzbicach, w 2010 roku dla Wrocławskiej Placówki Wielofunkcyjnej ,Dziecięcy Dom”, a w 2011 roku dla Specjalnego Ośrodka Szkolno-Wychowawczego nr 10 we Wrocławiu.

Doktor Marcin Winiarski sprawował także opiekę nad Klubem Żeglarskim „Fala”, którego był członkiem honorowym, a następnie nad Studenckim Klubem Żeglarskim Uniwersytetu Wrocławskiego „Przechyły”.

W 2013 roku został przyznany dr. Marcinowi Winiarskiemu Medal Komisji Edukacji Narodowej.

Bożena Górna

Teresa Korbutowicz

ORCID: 0000-0003-0422-8814

Uniwersytet Wrocławski

Studenckie Prace Prawnicze, Administratywistyczne

i Ekonomiczne 32, 2020

(C) for this edition by CNS 